\title{
Heterogeneity of Growth Hormone in the Nocturnal Serum of Children ${ }^{1}$
}

\author{
DANIEL RUDMAN, RAJENDER K. CHAWLA, AND MICHAEL H. KUTNER \\ Departments of Medicine and Biometry, Emory University School of Medicine, Atlanta, Georgia 30322 and \\ Department of Medicine, University of Health Sciences/The Chicago Medical School, \\ North Chicago, Illinois 60064
}

\begin{abstract}
The nocturnal serum of 13 nongrowth hormone deficient, hyposomatomedinemic short children and of 12 normal children of average height was analyzed by both polyclonal and biclonal radioimmunoassays. The biclonal/polyclonal ratio for immunochemical grade human growth hormone was 1.0, but for the nocturnal sera in both groups, this ratio was significantly less than 1.0 (range $0.5-1.2$, average $0.7-0.8$ ). The ratio did not differ significantly between the two groups of children. (Pediatr Res 19: 981-985, 1985)
\end{abstract}

\section{Abbreviations}

RIA, radioimmunoassay

GH, growth hormone

hPL, human placental lactogen

hPRL, human prolactin

hTSH, human thyroid-stimulating hormone

hFSH, human follicle-stimulating hormone

hLH, human luteinizing hormone

hGH, human growth hormone

RRA, radioreceptor assay

The purpose of this study was to compare the RIA profile of the endogenous $\mathrm{GH}$ between normal children of average height and hyposomatomedinemic non-GHD, short children identified in a preceding investigation (1) by means of newly available monoclonal RIA techniques (2) together with the conventional polyclonal assay (3). The gel-filtration behavior of the serum $\mathrm{GH}$ also was compared between the two groups of children.

\section{METHODS}

SUBJECTS

The normal group comprised six boys and six girls, 12 to 18 yr old, between the 5 th and 95 th percentiles in height. History and physical examination revealed no evidence of acute or chronic illness.

The hyposomatomedinemic, non-GHD, short (less than third percentile) children consisted of 10 boys and three girls, 7 to 10 $\mathrm{yr}$ of age, who had been identified during phase 2 of a preceding study (1). Their clinical characteristics are summarized in Table 2 of the preceding report (1). Mean serum immunoreactive $\mathrm{GH}^{2}$

Received October 22, 1984; accepted May 1, 1985.

Supported in part by NIH Grants AM-31149 and RR-00039 and by a grant from the Veterans Administration.

${ }^{1}$ Presented in part at a workshop on Human Growth Hormone, National Pituitary Agency, Baltimore, MD, October, 1984.

${ }^{2}$ The conventional, commercially available RIA with polyclonal rabbit antiserum was used to measure immunoreactive $\mathrm{GH}$ in the provocative test. Our technique for carrying out this RIA is described in "Methods." response to L-dopa or glucagon was $>12 \mathrm{ng} / \mathrm{ml}$, showing normal immunoreactive $\mathrm{GH}$ status.

\section{STUDY DESIGN}

The children were hospitalized for 5 days. They received no medications. The short children had not received hGH injections during the previous month. Their diet was 2300 calories, $100 \mathrm{~g}$ protein, $250 \mathrm{~g}$ carbohydrate, and $100 \mathrm{~g}$ fat. Via an inwelling heparin lock inserted at 2000-2100,5 ml heparinized blood were removed on retiring, and at $30,60,90$, and $120 \mathrm{~min}$ after sleep began. The blood was kept at $4^{\circ} \mathrm{C}$ until 800 , when it was spun; the serum was stored at $-20^{\circ} \mathrm{C}$ for up to $2 \mathrm{wk}$ before analysis by RIA (4). Some sera also were examined by gel filtration.

\section{MATERIALS}

The kits were obtained from Kallestad Laboratories (New York, NY) ("polyclonal kit") and from Hybritech Laboratories (Los Angeles, CA) ("biclonal kit"). Two mouse monoclonal antibodies (33.2 and 101.3) to hGH were purchased from Hybritech. According to the manufacturers, the antibodies were directed at different epitopes of the hGH molecule. The precipitating antibody (rabbit antiserum to mouse $\mathrm{IgG}$ ) was obtained from Calbiochem-Behring (Los Angeles, CA). The labeled hGH used in the monoclonal assays was obtained from Kallestad Laboratories. Immunochemical grade $\mathrm{hGH}$, used as the cold hormone in these assays, was from National Institutes of Health, Bethesda, MD, as were the other hormones-hPL, hPRL, hTSH, $\mathrm{hFSH}, \mathrm{hLH}$, and $\beta$-lipotropin. For gel filtration, Ultrogel AcA 44 was purchased from LKB (New York, NY), and disposable columns $(1 \times 50 \mathrm{~cm})$ from BioRad, Richmond, CA. All other reagents and chemicals were obtained from Sigma Chemicals Co., St. Louis, MO.

\section{ANALYTICAL METHODS}

The Polyclonal RIA. The polyclonal RIA kit was obtained from Kallestad Laboratories, Inc. It contained rabbit antiserum to $\mathrm{hGH}$, labeled ${ }^{125} \mathrm{I}-\mathrm{hGH}$, goat antiserum to rabbit gamma globulin, and $0.01 \mathrm{M}$ phosphate buffer containing bovine serum albumin. The assay was a double antibody sequential saturation technique. The samples were incubated with hGH antiserum and ${ }^{125} \mathrm{I}-\mathrm{hGH}$ to form $\mathrm{hGH}$-antibody complexes, which were then precipitated with the second antibody. The bound fractions were counted in a gamma counter.

In each assay, $\mathrm{GH}$-free human serum containing varying amounts $(1-30 \mathrm{ng} / \mathrm{ml})$ of National Institutes of Health immunochemical grade $\mathrm{hGH}$ provided the standard curve.

The Biclonal RIA. This comprised plastic beads coated with monoclonal mouse antibody to $\mathrm{hGH},{ }^{125} \mathrm{I}$-labeled monoclonal mouse antibody to hGH (different from the one coating the 
beads), and a buffer wash. The assay was a solid phase two-site assay. Samples bound to the antibody on the bead and to the different ${ }^{125}$ I-antibody. The bead was then washed to remove all unbound labeled antibody and counted in a gamma counter. As in the polyclonal RIA the standard curve was determined in each assay with immunochemical grade $\mathrm{hGH}$ dissolved in $\mathrm{GH}$-free serum from GHD children.

Two Monoclonal RIA's. Two RIA's using monoclonal mouse antibodies were developed. These assays were of the sequential saturation type; details are described below.

Optimal dilution of the monoclonal antibody. A stock solution of $1 \mathrm{mg} / \mathrm{ml}$ monoclonal antibody was serially diluted from 1 in 100 to 1 in 300,000 in assay buffer, a $0.01 \mathrm{M}$ phosphate solution of $\mathrm{pH} 7.4$ containing $0.5 \%$ bovine serum albumin. An aliquot $(500 \mu \mathrm{l})$ of the assay buffer was mixed with $100 \mu \mathrm{l}$ of each antibody dilution and $100 \mu \mathrm{l}$ of ${ }^{125} \mathrm{I}-\mathrm{hGH}$. The tubes were vortexed and incubated for $4 \mathrm{~h}$ at $37^{\circ} \mathrm{C}$. Thereafter, $200 \mu \mathrm{l}$ of the precipitating antibody solution was mixed into each tube of the assay. Precipitating antibody was rabbit antiserum to mouse $\operatorname{IgG}$ supplied by Calbiochem-Behring. This was diluted one in five parts in assay buffer, and then equally with $12 \%$ polyethylene glycol. The total assay mixture was then incubated for $16 \mathrm{~h}$ at $4^{\circ}$ $\mathrm{C}$, after which the tubes were centrifuged for $30 \mathrm{~min}$ at $3000 \times$ $g$. The supernatant was decanted and the residue counted in a gamma counter. The percent absolute binding was plotted against the dilution to determine the dilution of monoclonal antibody which bound about $30 \%$ of the labeled hGH.

Displacement Curve. After the optimal antibody dilution was determined, a displacement curve of the antibody using varying amounts of immunochemical hGH was examined for sensitivity and specificity. The assay was based on sequential saturation technique where $500 \mu \mathrm{l}$ of assay buffer, $100 \mu \mathrm{l}$ diluted antibody, and $100 \mu \mathrm{l}$ of sample were incubated for $4 \mathrm{~h}$ at $37^{\circ} \mathrm{C}$. The standards ( 3 to $100 \mathrm{ng} / \mathrm{ml}$ immunochemical grade $\mathrm{hGH}$ ) were prepared in GH-free human serum. Nonspecific binding was determined by spiking duplicate tubes in the assay with $10 \mu \mathrm{g}$ hGH in place of sample or standard. After the initial $4 \mathrm{~h}$ incubation, $100 \mu \mathrm{l}$ of ${ }^{125} \mathrm{I}$-hGH were mixed into all tubes and incubated for $2 \mathrm{~h}$ at $37^{\circ} \mathrm{C}$. The precipitating antibody solution $(200 \mu \mathrm{l})$ was then added. The entire assay mixture was incubated for $16 \mathrm{~h}$ at $4^{\circ} \mathrm{C}$ and then spun, drained and counted in order to calculate the percent of bound ${ }^{125} \mathrm{I}-\mathrm{hGH}$ in each tube. A log-logit plot was established to correlate percent binding and the amount of hormone in the standard samples. As in the polyclonal and biclonal assays, control sera containing known amounts of the immunochemical grade $\mathrm{hGH}$ were included in each assay of unknown sera. In addition to tests of sensitivity, and inter- and intraassay variability, the antibody was tested for specificity to hGH. Cross-reactivity was measured by testing the ability of adrenocorticotropic hormone, hPRL, hTSH, hLH, hPL, hFSH and $\beta$-lipotropin, to displace the labeled hGH.

Gel Filtration Analyses. The chromatography was carried out on a $1 \times 50 \mathrm{~cm}$ Ultrogel AcA 44 column. The eluting buffer was $0.023 \mathrm{M}$ ammonium carbonate, $\mathrm{pH} 8.6$, with $0.1 \%$ bovine albumin and $0.02 \%$ sodium azide.

The column and buffer were stored at $4^{\circ} \mathrm{C}$ and were run at $25^{\circ} \mathrm{C}$. One $\mathrm{ml}$ aliquot of a child's nocturnal serum was loaded on the column. The flow rate was $1 \mathrm{ml} / 1.5 \mathrm{~min}$ and $1 \mathrm{ml}$ fractions were collected. The fractions were separately lyophilized, reconstituted in $250 \mu \mathrm{l}$ of water, and assayed in the polyclonal and biclonal RIA's.

\section{RESULTS}

\section{DATA ON THE FOUR RIA SYSTEMS}

Polyclonal (Kallestad) Assay. The intraassay and interassay coefficients of variation were 4 and $6 \%$, respectively. No detectable cross-reactivity $(<0.01 \%)$ was observed with hFHS, hLH, hTSH, or hPL. Human prolactin cross-reacted with $2.5 \%$ of the activity of hGH. The sensitivity of the assay was $1.0 \mathrm{ng} / \mathrm{ml}$ and the working range was $1-12 \mathrm{ng} / \mathrm{ml}$.

Biclonal (Hybritech) Assay. Intra- and interassay coefficients of variation were 3 and $6 \%$. Cross-reactivity of hLH, hFSH, or hPL was $<0.01 \%$, while cross-reactivity of human prolactin was $0.5 \%$. The sensitivity of the assay was $0.2 \mathrm{ng} / \mathrm{ml}$ and the working range was $1.0-25.0 \mathrm{ng} / \mathrm{ml}$.

Monoclonal RIA. Determination of optimal dilution of antibody. A maximal binding of $50 \%$ for 33.2 , and of $42 \%$ for 101.3 , was obtained at a dilution of 1 in 1000 . The binding became undetectable $(<4 \%)$ at a dilution of 1 in 100,000 for 33.2 , and of 1 in $1,000,000$ for 101.3. At a dilution of 1 in 30,000 , the absolute binding ranged from 30 to $35 \%$ for 101.3 . At a dilution of 1 in 3000 , the absolute binding ranged from 30 to $35 \%$ for 33.2. These latter dilutions of antibody were used for all subsequent assays.

The intra- and interassay coefficients of variation for degree of binding were 3 and $6 \%$. Stock solutions of antibody 33.2 and 101.3 (diluted 1 in 3000) were kept frozen in $1 \mathrm{ml}$ aliquots, and diluted for use in each assay as required. No change in binding was noticed in frozen aliquots over a period of $12 \mathrm{wk}$.

Displacement curves for each antibody. Figure 1 shows dis-
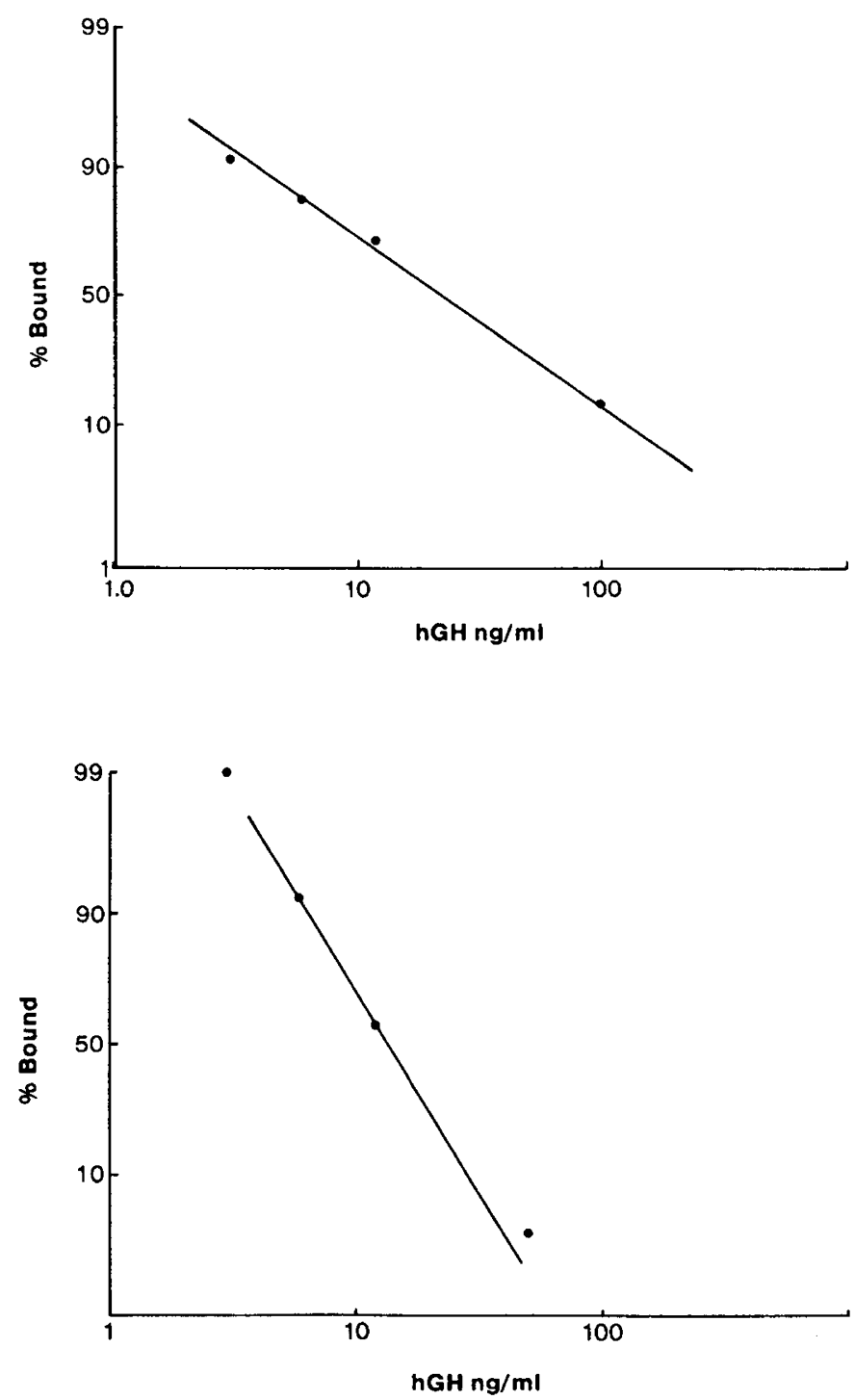

Fig. 1. Upper: Displacement curve for monoclonal antibody 101.3 using immunochemical grade hGH standards of $3,6,12,25$, and $50 \mathrm{ng} /$ $\mathrm{ml}$ and ${ }^{125} \mathrm{I}-\mathrm{hGH}$. Lower: Displacement curve for monoclonal antibody 33.2 using immunochemical grade hGH standards as defined in Figure $1 \mathrm{~A}$. 
placement curves for each monoclonal antibody. The intra- and interassay coefficients of variation averaged 5 and $9 \%$ for both antibodies. The assay showed no significant cross-reactivity $(<0.05 \%)$ with adrenocorticotropic hormone, hTSH, hFSH, hPL, or $\beta$-lipotropin. Human prolactin cross-reacted about $0.5 \%$. For $33.2,15 \mathrm{ng} / \mathrm{ml} \mathrm{hGH}$ was required for $50 \%$ displacement. For 101.3 , only $12 \mathrm{ng} / \mathrm{ml}$ was required for similar displacement.

The useable range for 33.2 was $1-32 \mathrm{ng} / \mathrm{ml}$ and for 101.3 was $8-100 \mathrm{ng} / \mathrm{ml}$. The sensitivities of the two monoclonal RIA's were $16 \mathrm{ng} / \mathrm{ml}$ and $8 \mathrm{ng} / \mathrm{ml}$ respectively.

\section{SLEEP TESTS}

Normal Children and Adolescents, 12 to 18 Yr Old. A typical sleep test is shown in Figure 2, and the group is summarized in Table 1 . On retiring, the polyclonal serum $\mathrm{GH}$ value averaged less than $1 \mathrm{ng} / \mathrm{ml}$. At 30 and $60 \mathrm{~min}$, it averaged $14 \mathrm{ng} / \mathrm{ml}$, then declined progressively during the next $90 \mathrm{~min}$. Because the biclonal and polyclonal assays had similar thresholds, about 1
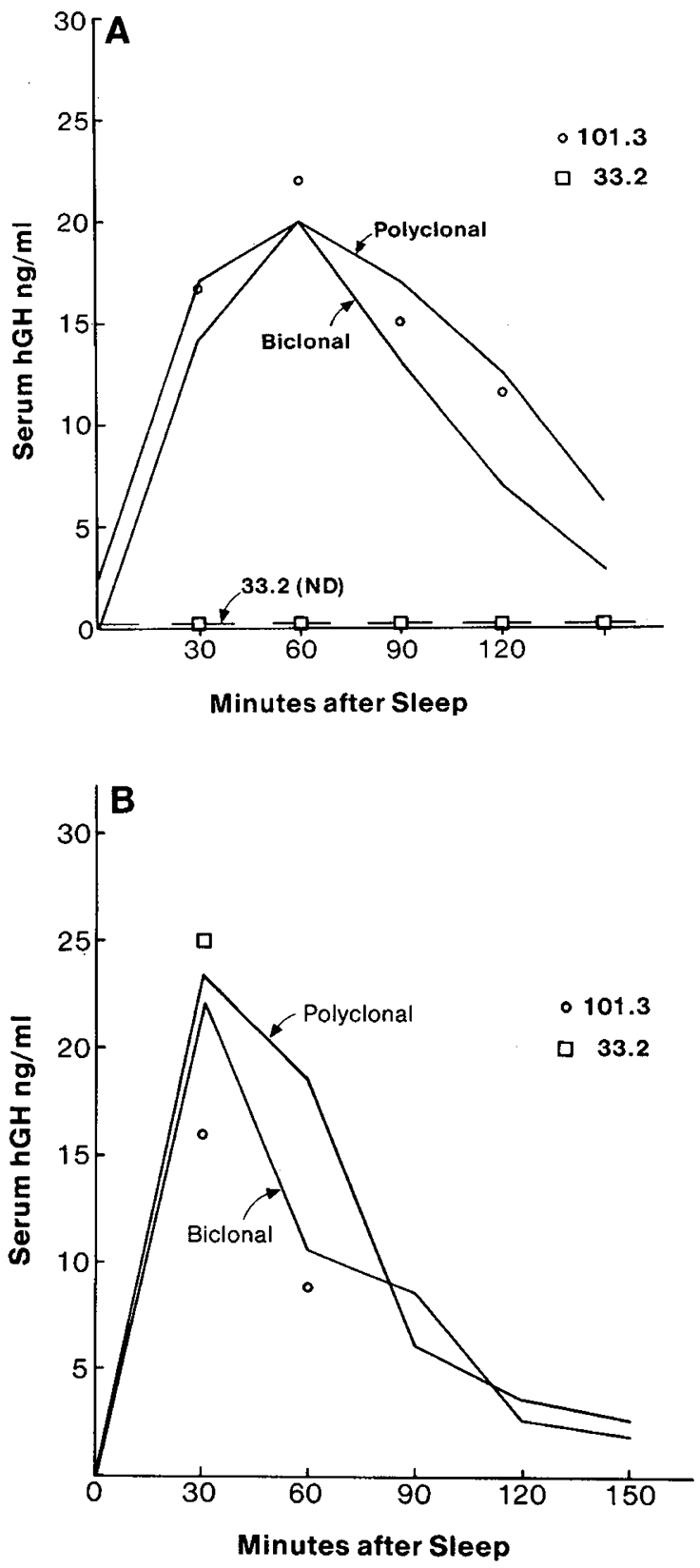

Fig. 2. Typical sleep tests comparing nocturnal serum hGH levels of a normal $(A)$ and a non-GHD, hyposomatomedinemic, short child $(B)$ as measured by four types of RIA.
Table 1. Nocturnal immunoreactive serum GH in normal and non-GHD hyposomatomedinemic short-children as measured by four types of RIA (mean $\pm S D)$

\begin{tabular}{|c|c|c|}
\hline & Normal & Non-GHD* \\
\hline Peak polyclonal (ng/ml) & $20.0 \pm 2.2(n=12)$ & $17.7 \pm 2.4(n=13)$ \\
\hline Peak biclonal/polyclonal & $0.84 \pm 07 \dagger$ & $0.81 \pm 0.07 \dagger$ \\
\hline $\begin{array}{l}\text { Peak } 33.2 \text { monoclonal/ } \\
\text { polyclonal }\end{array}$ & $1.28 \pm 0.35(n=5)$ & $1.18 \pm 0.13(n=6)$ \\
\hline $\begin{array}{l}\text { Peak } 101.3 \text { monoclonal/ } \\
\text { polyclonal }\end{array}$ & $0.90 \pm 0.41(n=8)$ & $0.98 \pm 0.24(n=9)$ \\
\hline $\begin{array}{l}33.2 \text { monoclonal } \\
(\% \text { ND } \ddagger)\end{array}$ & $58(7 / 12)$ & $45(5 / 11)$ \\
\hline $\begin{array}{l}101.3 \text { monoclonal } \\
(\% \text { ND } \S)\end{array}$ & $27(3 / 11)$ & $10(1 / 10)$ \\
\hline $\begin{array}{l}30 \mathrm{~min} \text { polyclonal } \\
(\mathrm{ng} / \mathrm{ml})\end{array}$ & $13.9 \pm 2.9(n=12)$ & $15.1 \pm 2.9(n=13)$ \\
\hline $\begin{array}{l}30 \text { min biclonal/poly- } \\
\text { clonal }\end{array}$ & $0.83 \pm 0.09 \dagger$ & $0.79 \pm 0.07 \dagger$ \\
\hline $\begin{array}{l}30 \text { min } 33.2 \text { monoclonal/ } \\
\text { polyclonal }\end{array}$ & $1.14 \pm 0.11(n=3)$ & $1.19 \pm 0.57(n=5)$ \\
\hline $\begin{array}{l}30 \mathrm{~min} 101.3 \mathrm{monoclo-} \\
\mathrm{nal} / \text { polyclonal }\end{array}$ & $1.00 \pm 0.10(n=7)$ & $1.06 \pm 0.58(n=7)$ \\
\hline 33.2 monoclonal (\% ND) & $75(9 / 12)$ & $55(6 / 11)$ \\
\hline $\begin{array}{l}101.3 \text { monoclonal } \\
(\% \mathrm{ND})\end{array}$ & $36(4 / 11)$ & $30(3 / 10)$ \\
\hline $\begin{array}{l}60 \mathrm{~min} \text { polyclonal } \\
(\mathrm{ng} / \mathrm{ml})\end{array}$ & $14.4 \pm 2.5(n=11)$ & $12.6 \pm 2.4(n=13)$ \\
\hline $\begin{array}{l}60 \text { min biclonal/poly- } \\
\text { clonal }\end{array}$ & $0.81 \pm 0.06 \dagger$ & $0.69 \pm 0.04 \dagger$ \\
\hline $\begin{array}{l}60 \mathrm{~min} 33.2 \text { monoclonal/ } \\
\text { polyclonal }\end{array}$ & $1.16 \pm 0.28(n=4)$ & $0.98 \pm 0.47(n=3)$ \\
\hline $\begin{array}{l}60 \mathrm{~min} 101.3 \text { monoclo- } \\
\mathrm{nal} / \text { polyclonal }\end{array}$ & $1.46 \pm 1.25(n=8)$ & $1.72 \pm 1.95(n=4)$ \\
\hline 33.2 monoclonal (\% ND) & $67(8 / 12)$ & $73(8 / 11)$ \\
\hline $\begin{array}{l}101.3 \text { monoclonal } \\
(\% \mathrm{ND})\end{array}$ & $27(3 / 11)$ & $60(6 / 10)$ \\
\hline
\end{tabular}

${ }^{*} p>.05$ for comparison of all variables between normal and nonGHD groups.

$\dagger$ Significantly less than $1(p<0.05)$.

$\ddagger$ Not detectable: $<16 \mathrm{ng} / \mathrm{ml}$.

$\S$ Not detectable: $<8 \mathrm{ng} / \mathrm{ml}$.

$\mathrm{ng} / \mathrm{ml}$, the biclonal to polyclonal ratio was calculated for all of the sera which contained $>1 \mathrm{ng} / \mathrm{ml}$ or more of polyclonal immunoreactivity. At 30 and $60 \mathrm{~min}$, the average ratio was significantly less than one by Student's $t$ test, being 0.83 and 0.81 , respectively $(p<0.05)$.

At 30 and $60 \mathrm{~min}$, the 33.2 monoclonal reactivity was below its threshold of $16 \mathrm{ng} / \mathrm{ml}$ in 75 and $67 \%$ of the samples, respectively; and the 101.3 assay was below its sensitivity of $8 \mathrm{ng} / \mathrm{ml}$ in 36 and $27 \%$ of the samples. For samples in which the 33.2 monoclonal assay was above its threshold sensitivity of $16 \mathrm{ng} /$ $\mathrm{ml}$, the 33.2 to polyclonal ratio averaged $1.14(30 \mathrm{~min})$ and 1.16 ( $60 \mathrm{~min}$ ) (not significantly different from 1.0 by Student's $t$ test). For samples in which the 101.3 monoclonal assay was above its threshold of $8 \mathrm{ng} / \mathrm{ml}$, the 101.3 to polyclonal ratio averaged 1.00 (30 $\mathrm{min})$ and $1.46(60 \mathrm{~min})$ (not significantly different from one).

Biclonal to polyclonal ratios for individual normal children varied between 0.54 and 1.20. The 101.3 and 33.2 to peak polyclonal ratios for individual normal children varied between 0.52 and 1.64 for 101.3 and between 1.06 and 1.27 for 33.2. By single factor analysis of variance techniques, we found generally significant $\mathrm{F}$ ratios $(p<0.05)$, indicating that some subjects had statistically different ratios. ${ }^{3}$

\footnotetext{
${ }^{3}$ These data are filed with the National Auxiliary Publication Service as document 04319
} 
Hyposomatomedinemic, Non-GHD, Short Children, 7 to 10 $Y r$ Old. A representative sleep test is shown in Figure $2 B$ and the results for the entire group are summarized in Table 1 . The polyclonal $\mathrm{GH}$ immunoreactivity usually peaked at $30 \mathrm{~min}$, occasionally at $60 \mathrm{~min}$. The peak polyclonal value averaged 17.7 $\mathrm{ng} / \mathrm{ml}$.

At 30 and $60 \mathrm{~min}$, the biclonal to polyclonal ratio was significantly less than one, being 0.79 and 0.69 respectively. As shown in Table 2 of the preceding report, the average biclonal to polyclonal ratio in the non-GHD, hyposomatomedinemic short children ranged from 0.52 to 1.18 .

At 30 and $60 \mathrm{~min}, 55$ and $73 \%$ of the samples had undetectable monoclonal 33.2 level $(<16 \mathrm{ng} / \mathrm{ml})$, while 30 and $60 \%$ were undetectable in the monoclonal 101.3 assay $(<8 \mathrm{ng} / \mathrm{ml})$. For those samples above the thresholds in the 33.2 and 101.3 monoclonal assays, the 33.2/polyclonal and 101.3/polyclonal ratios averaged 1.19 and 1.06 at $30 \mathrm{~min}$ and 0.98 and 1.72 at $60 \mathrm{~min}$, respectively (not significantly different from one by Student's $t$ test, $p>0.05$ ).

Statistical Comparisons between Normal (Age 12 to 18) and Hyposomatomedinemic, Non-GHD Short Children (Age 7 to 10). With Student's $t$ test or Fisher's exact test for comparing percentages, no significant differences in any of the serum GH imunochemical levels or ratios shown in Table 1 were found between the groups.

\section{INCUBATION EXPERIMENTS}

After the differing results in the four RIA's were recognized, the possibility was considered that the native hGH molecule was degraded in blood, with differential effects of the degradation process on immunoreactivity in the four assays. To investigate this question, we incubated either clinical grade or immunochemical grade hGH $(20 \mathrm{ng} / \mathrm{ml})$ in heparinized blood from a GHD child $(<1.0 \mathrm{ng} / \mathrm{ml}$ of endogenous serum GH by the polyclonal RIA), and in the corresponding plasma at $25^{\circ} \mathrm{C}$ or at $37^{\circ}$ $\mathrm{C}$, under either air or $95 \% \mathrm{O}_{2}+5 \% \mathrm{CO}_{2}$. In none of the four assays did immunoreactive levels change significantly during 5 $h$ of incubation.

\section{GEL-FILTRATION ANALYSES}

Twenty-six nocturnal sera containing $>10 \mathrm{ng} / \mathrm{ml} \mathrm{GH}$ in the polyclonal RIA ( 12 normal subjects and 14 hyposomatomedinemic non-GHD short children) were examined by gel-filtration chromatography. For comparison, $20 \mathrm{ng} / \mathrm{ml}$ of immunochemical grade hGH were added to the serum of a GHD child, and this sample also was analyzed. Typical results are shown in Figure 3. After chromatography of the serum containing added $\mathrm{hGH}$, the polyclonal immunoreactivity eluted between fractions 36 and

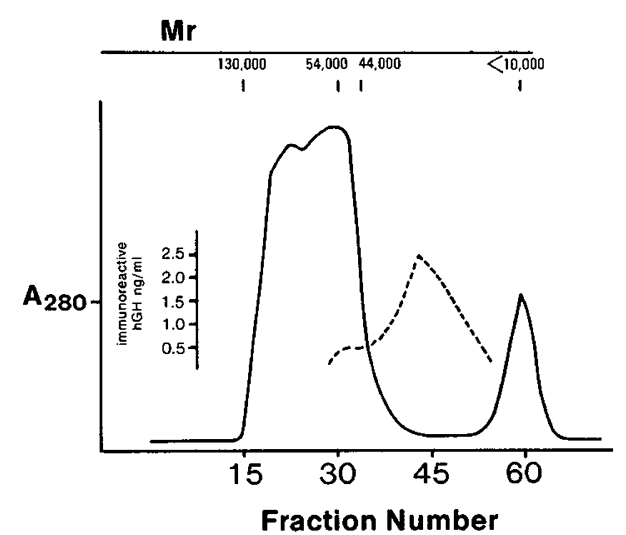

Fig. 3. Gel-filtration profile of GH-deficient serum spiked with immunochemical grade hGH on Ultrogel ACA44. Solid line indicates absorption at $280 \mathrm{~mm}$. Broken line is immunoreactive $\mathrm{GH}$ determined by the polyclonal assay.
42 , with a peak at tube 40 . The overall recovery was about $80 \%$. No other polyclonal immunoreactive peak was observed. The same type of chromatogram was obtained in all 26 nocturnal serum samples. The overall recovery of the serum polyclonal immunoreactivity ranged from $65-90 \%$ and was in fractions 36 to 42 . The biclonal to polyclonal ratio of the recovered $\mathrm{GH}$ immunoreactivity did not differ significantly from that in the serum applied to the column.

Similar results were obtained when the GHD serum containing $20 \mathrm{ng} / \mathrm{ml}$ added immunochemical hGH was stored at $5^{\circ} \mathrm{C}$ for 8 $\mathrm{h}$ before gel filtration.

\section{DISCUSSION}

The average biclonal/polyclonal immunoreactivity ratio of nocturnal serum was significantly below 1.0 in both normal and hyposomatomedinemic, non-GHD, short children. If the endogenous GH in these sera was identical to the native hGH molecule which was used to standardize the four RIAs, this ratio would have been 1.0 . Because the average ratio was 0.7 to 0.8 , at least $20-30 \%$ of the endogenous $\mathrm{GH}$ probably differs in structure from the native hormone molecule. One possibility would be a mixture of about 75 parts of the native molecule with biclonal/ polyclonal ratio $=1.0$, and 25 parts of an altered molecule with a ratio $=0$. Alternatively, all the endogenous $\mathrm{GH}$ could be an altered form of hGH with a biclonal/polyclonal ratio of 0.75 . Intermediate hypotheses are possible. The extensive intra- and interindividual differences in the biclonal/polyclonal and monoclonal/polyclonal ratio (range, 0.5 to 1.5$)^{3}$ suggest that endogenous serum GH probably is a complex mixture of altered forms. However, the possibility cannot be excluded that the standard hGH molecule was not itself native, but was altered by its purification. Because the antigenic specificities of the five antisera used in the four RIAs are not defined, we cannot speculate about where in the hGH molecule the alterations occurred.

The structural alteration or heterogeneity responsible for the low biclonal/polyclonal ratio could arise in the pituitary gland, where two different GH genes are present, where the primary gene transcript is clipped and spliced, where the pre-GH product of the ribosomes is proteolytically shortened, and where structurally different forms of $22 \mathrm{~K} \mathrm{GH}$ have been recognized (5). Alternatively, the low biclonal/polyclonal ratio of the serum GH could reflect alteration of native GH by peripheral tissues, with reentry of modified GH molecules into the blood. The incubation experiments (see "Results") gave no evidence that exposure of hGH to plasma or blood constituents altered the hormone's immunoreactivity.

The absence of a statistically significant difference in any feature of the RIA profile, or in the gel-filtration chromatogram, between normal and non-GHD, hyposomatomedinemic short children, argues against the bioinactive GH hypothesis for the latter group as a whole. However, the considerable interindividual differences in the various RIA ratios within each group ${ }^{3}$ makes it impossible to exclude this possibility in every case. Furthermore, the gel-filtration technique used was probably not capable of distinguishing between $22 \mathrm{~K}$ and $20 \mathrm{KGH}$.

Besides the RIA profile and gel chromatogram, other ways of searching for bioinactive GH are by RRA and bioassay. Recently we compared serum GH by the pregnant rabbit liver RRA, by the human "IM9" lymphocyte RRA, by the NB2 mouse lymphoma bioassay, and by the polyclonal RIA in 12 control and in 4 hyposomatomedinemic, non-GHD, short children (6). Ratios of RRA/RIA and of bioassay/RIA ranged from as low as 0.36 to as high as 1.65 for nocturnal serum $\mathrm{GH}$ in both groups of children. Furthermore, RRA/RIA ratios averaging only 0.6 were observed by Sneid et al. (7) on serum GH during pharmacologic provocative tests in short normal children. These findings with RRA and bioassay methods are consistent with the present conclusion that serum GH is heterogeneous in children of both average and below average height. 


\section{REFERENCES}

1. Rudman D, Kutner MH, Chawla RK 1985 The short child with subnormal plasma somatomedin C. Pediatr Res 19:000-000

2. Schalch DS, Parker ML 1964 A sensitive double antibody immunoassay for human growth hormone in plasma. Nature 203:1141

3. Bundesen PG, Drake RG, Kelly K, Worsley IG, Friesen HG, Sehon AH 1980 Radioimmunoassay for human growth hormone using monoclonal antibodies. J Clin Endocrinol Metab 57:1472

4. Furlanetto RW, Underwood LE, Van Wyk JJ, D'Ercole AJ 1977 Estimation of somatomedin-C levels in normals and patients with pituitary disease by radioimmunoassay. J Clin Invest 60:648-657
5. Chawla RK, Parks JS, Rudman D 1983 Structural variants of human growth hormone. Ann Rev Med 34:519-547

6. Tokuhiro E, Dean HJ, Friesen HG, Rudman D 1984 Comparative study of serum human growth hormone measurement with NB2 lymphoma cell bioassay, IM-9 receptor modulation assay, and radioimmunoassay in children with disorders of growth. J Clin Endocrinol Metab 58:549

7. Sneid D, Jacobs LS, Weldon VV, Daughaday WH 1975 Radioreceptor-inactive growth hormone associated with stimulated secretion in normal subjects. J Clin Endocrinol Metab 41:471

8. Snedecor GW, Cochran WG 1980 Statistical Methods, 7th ed. The Iowa State University Press, Ames, IA 